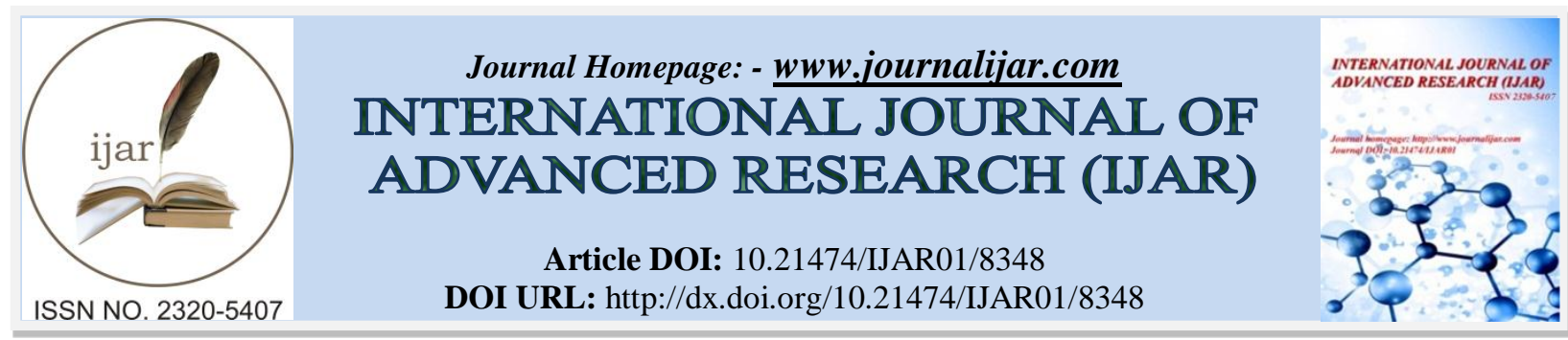

RESEARCH ARTICLE

\title{
EVALUATION OF ANTIBIOFILM ACTIVITY OF THE LATEX EXTRACTED FROM Himatanthus drasticus (Mart.) Plumel (JANAGUBA)
}

Danielle Feijó de Moura ${ }^{1}$, Carlos Roberto Weber Sobrinho ${ }^{2}$, Dayane de Melo Barros ${ }^{3}$, José Luciano Brainer de Farias Filho ${ }^{2}$, Alexandre Gomes da Silva ${ }^{4,5}$, Tamiris Alves Rocha ${ }^{1}$, Sheila Taise Fernandes e Silva ${ }^{2}$, Marllyn Marques da Silva ${ }^{6}$, René Duarte Martins ${ }^{7}$, Márcia Vanusa da Silva ${ }^{1,5}$.

1. Laboratório de Biologia Molecular, Departamento de Bioquímica, Universidade Federal de Pernambuco, Pernambuco, Brasil.

2. Laboratório de Microbiologia e Imunologia Aplicada, Universidade Federal de Pernambuco, Pernambuco, Brasil.

3. Laboratório de Microbiologia de Alimentos, Centro Acadêmico de Vitória, Universidade Federal de Pernambuco, Pernambuco, Brasil.

4. Departamento de Antibióticos, Universidade Federal de Pernambuco, Pernambuco, Brasil.

5. Núcleo de Bioprospecção da Caatinga, Instituto Nacional do Semiárido, Paraíba, Brasil.

6. Laboratório de Nanotecnologia, Biotecnologia e Cultura de Células (NANOBIOCEL), Centro Acadêmico de Vitória, Universidade Federal de Pernambuco, Pernambuco, Brasil.

7. Espaço Farmácia Viva, Centro Acadêmico de Vitória, Universidade Federal de Pernambuco, Pernambuco, Brasil.

\section{Manuscript Info}

Manuscript History

Received: 08 November 2018

Final Accepted: 10 December 2018

Published: January 2019

Key words:-

plants, latex, Pseudomonas aeruginosa, Staphylococcus aureus, biological activities.

\section{Abstract}

The secondary metabolites present in plants often have antibiofilm activity, this property attributed to plant compounds is of great importance, given the formation of biofilms in biomaterials, which further boosts the search for natural substances capable of minimizing this type of formation. Himatanthus drasticus (Mart.) Plumel is a tree species popularly known as janaguba, this is found in areas of caatinga, cerrado, rupestrian fields and rainforest. Community empirical knowledge attributes to this plant species therapeutic action against tumors, hemorrhoids, respiratory tract infections, digestive tract and urogenital tract. Considering the reduced number of scientific findings on the biological activities of $H$. drasticus latex, the objective of the present study was to verify the antibiofilm activity of its latex. The latex was extracted from $H$. drasticus specimens, where a small area of the vegetal bark $(5 \times 30 \mathrm{~cm})$ was removed, later the latex was dissolved in water and lyophilized. For the microbiological assays, the ATCC standards of Pseudomonas aeruginosa and Staphylococcus aureus were cultured in BHI broth for 24 hours at $37{ }^{\circ} \mathrm{C}$. The assay was performed with flat-bottomed 96 well plates, and the latex extracted from $H$. drasticus and bacterial suspensions were added to the BHI broth. Negative Control (NC) was used as broth BHI and Positive Control (PC), the PA01 strain of P. aeruginosa as this strain is indicated as a positive control for biofilm assays. The plates were then incubated at $37^{\circ} \mathrm{C}$ for 24 hours. After this period, the absorbance was read in an

Corresponding Author:- Danielle Feijó de Moura.

Address:- Laboratório de Biologia Molecular - Departamento de Bioquímica, Universidade

Federal de Pernambuco - Pernambuco, Brasil. 
ELISA reader with wavelength of $570 \mathrm{~nm}$, then the samples were classified. The antibiofilm activity of the latex extracted from $H$. drasticus was classified as non-adherent on the species $P$. aeruginosa and $S$. aureus. Thus, the study revealed that $H$. drasticus latex has a potential antibiofilm action, however, additional studies should be carried out in order to evaluate other aspects associated with the biological activities performed by this plant species.

Copy Right, IJAR, 2018,. All rights reserved.

\section{Introduction:-}

The formation of biofilms in biomaterials such as orthopedic prostheses, catheters, dental implants and probes, has been increasing over the years. These biomaterials are susceptible to microbial colonization and favor the development of infections, characterizing as an important source of transmission of resistant pathogens in hospitals and clinics. In order to minimize the formation of biofilms, several researches have been developed to identify substances capable of preventing the colonization and proliferation of these microorganisms (ARCIOLA et al., 2012; LIM et al., 2013).

Against this, microbicidal substances derived from medicinal plants have been tested for their applicability under the formation of bacterial biofilms. These, in turn, should be carefully analyzed, to be used safely in the development of new products. It is also worth noting that mechanisms of action that combine antibiofilm agents with conventional antibiotic therapy are primordial for the control of Healthcare Associated Infections - HAIs (CEGELSKI et al., 2008; BELOIN et al., 2014).

Himatanthus drasticus (Mart.) Plumel is a tree species, with dense foliage at the extremities of the branches, located only in Brazilian territory. It has as characteristics a milky latex that is commonly used in the treatment of cancer in some regions of the Northeast. According to Plumel (1991) and Soares et al. (2015), the popular names of this species are distinguished according to the regions, among the denominations are: tiborna, raivosa e jasmim-manga (in the Southeast), janaguba or pau-de-leite (in the Northeast) and sucuuba (in the North).

In Ceará, this species occurs with greater distribution in the Chapada do Araripe, its use predominates among the communities of the state, for anti-inflammatory purposes, in addition, several structures of the plant are used, in addition to latex, with therapeutic purpose, such as leaves and the shell (KAPLAN, 1967).

The biological activity is in full investigation, since its medicinal use is consolidated in several regions of Brazil for the treatment of several diseases, especially in the fight against cancer cells. Its extracts also act in the fight against infections of the respiratory tract, digestive tract, urogenital tract and hemorrhoids (KAPLAN, 1967), also revealing bactericidal, fungicidal, antiviral, analgesic and antiallergic activities (PATOCKA, 2003).

Therefore, the present study had as objective to evaluate the antibiofilm activity of latex extracted from $H$. drasticus.

\section{Methodology:-}

Latex was collected from specimens of $H$. drasticus, in the Araripe - Apodi National Forest, state of Ceará, Brazil. The botanical material was identified in Herbarium Dárdano de Andrade - Lima, IPA (Instituto Agronômico de Pernambuco, Recife, Brazil). The collection was done by cutting a small area $(5 \times 30 \mathrm{~cm})$ of bark from the trunk of the plant (LUCETTI, 2010). An exsicata of the plant was directed to the Herbarium of the IPA in Recife - PE, receiving the code 92.408 .

The technique performed for the study was described by Stepanović et al. (2000), with some modifications. Isolates of Pseudomonas aeruginosa ATCC 278553 and Staphylococcus aureus ATCC 29213 were grown in BHI broth for 24 hours at $37^{\circ} \mathrm{C}$. Then, the bacterial suspensions were applied to polystyrene plates containing flat bottom 96 wells for microtiter, in triplicate, and BHI broth and latex extracted from H. drasticus at a concentration of $50 \mathrm{mg} / \mathrm{mL}$ were added. The BHI broth and Positive Control (PC), the PA01 strain of P. aeruginosa, were used as Negative Control (NC), since this strain is established as a positive control for biofilm assays. 
The plates were then incubated at $37^{\circ} \mathrm{C}$ for 24 hours, after which time the bacterial suspensions were removed and each well was washed three times with $250 \mu \mathrm{L}$ of sterile physiological solution $(0.9 \% \mathrm{NaCl})$. Subsequently, fixation was performed with $200 \mu \mathrm{L}$ of methanol P.A. for 15 minutes, after which the methanol was removed, the plates were left at room temperature to dry and stained with $200 \mu \mathrm{L}$ of crystal violet solution for five minutes. The plates were washed with running water and dried at room temperature, after which the absorbance reading was performed on an ELISA reader (BioRad, model 550), wavelength $570 \mathrm{~nm}$ and the samples were classified according to Stepanović et al. (2000).

The value of the Optical Densities for each isolate (DOi) was obtained from the mean of the three wells, this value being compared to the Optical Density of the negative control (DOc). The isolates were classified into four categories according to the mean of the Optical Densities (Dos) related to the DOc results. The categories were based on the following criteria: non-adherent: DOi $\leq$ DOc; weakly adherent $(+)$ : DOc $<$ DOi $\leq 2 x D O c$; moderately adherent $(++)$ : $2 x$ ODc $<$ ODD $\leq 4 x D O c$ or strongly adherent $(+++)$ : 4x ODc $<$ DOi.

\section{Results and Discussion:-}

Considering the classification criteria established by Stepanović et al. (2000), the antibiofilm activity of latex extracted from $H$. drasticus was classified as non-adherent on P. aeruginosa and $S$. aureus species (Table 1).

Table 1:-Antibiofilm activity of latex extracted from $H$. drasticus.

\begin{tabular}{|c|c|}
\hline Bacterial species & Latex antibiotic activity \\
\hline P. aeruginosa & Non-stick \\
\hline S. aureus & Non-stick \\
\hline
\end{tabular}

The data obtained are considered satisfactory, since $P$. aeruginosa is reported as a versatile Gram-negative bacterium and commonly associated with Healthcare-associated Infections (HAIs). This microorganism easily adheres to several types of biomaterials; in addition, due to virulence factors and high resistance to antibiotics, its proliferation is difficult to control (STREETER and KATOULI, 2016).

According to Tintino et al. (2013), P. aeruginosa is highly efficient in the formation of biofilms, a property used for protection of host defense and antibiotic action. As for the activity of $S$. aureus, this species resembles $P$. aeruginosa due to its capacity to form biofilms and its relation with HAIs. However, it behaves opportunistically and may cause, in more severe situations, bacteremia, pneumonia, osteomyelitis, meningitis and cardiac inflammation (endocarditis, myocarditis and pericarditis). This microorganism has potentially increased its resistance to antibiotic therapy, making its control increasingly complex (PEREIRA et al., 2004, TRABULSI and ALTERTHUM, 2009).

Trentin, Giordani and Macedo (2014) reported that the development of new strategies that prevent the formation of biofilm has received notoriety, especially in biomaterials, since the antibiofilm action can occur by blocking bacterial cell adhesion under a certain surface or through of the breakdown of bacterial cell communication (Quorum Sensing - QS).

Several studies have described the action performed by P. aeruginosa and S. aureus on the formation of biofilms. According to Grenho (2012), after evaluating the adhesion of $P$. aeruginosa and $S$. aureus on nanohydroxyapatite and zinc oxide (nanoHA- $\mathrm{ZnO}$ ), it was verified that the bioamaterials used showed efficiency against the reduction of microbial growth and also in the constitution of biofilm.

Leite (2008) verified the colonization of bacteria and the formation of biofilms on both surfaces (polypropylene and polyurethane), strengthening the properties of $P$. aeruginosa and $S$. aureus under the formation of biofilm in facial dermosion wires. Bacteria of adhesion in the formation of biofilm in different types of materials, in addition, it was evidenced the importance of new studies that elucidate the viability of the antiaggregation of these bacteria against biomaterials in order to reduce the formation of biofilms.

A recent study by Moura (2016) revealed the antibacterial activity of latex extracted from $H$. drasticus against $P$. aeruginosa, Acinetobacter baumannii ATCC 19606, Enterobacter cloacae ATCC 13047, Escherichia coli ATCC 25922, Salmonella sp. ATCC 14028 and Shigella sp. ATCC 12022 and Gram-positive S. aureus, Kocuria rhizophila 
ATCC 9341, Methicillin-resistant Staphylococcus aureus (MRSA) from wounds and Streptococcus pyogenes (clinical strain), corroborating with the present results in view, the function of latex inhibit bacterial growth.

In other findings, the properties of latex of $H$. drasticus were also presented, revealing functions: anti-inflammatory, antibacterial and antifungal due to the presence of triterpene, secondary metabolite (PATOCKA, 2003; SPARG et al., 2004; ZHANG et al., 2008; POPOVA et al., 2009; SAEIDNIA, et al., 2014; CARMO, 2015; MOURA, 2016).

The antibiofilm action developed by the latex H. drasticus, can be attributed to its chemical composition. According to Moura (2016) the species H. drasticus is constituted among other components by terpenes (monoterpernes, sesquiterpenes and triterpenes).

Borowski (2015), investigated the antibiofilm capacity of isolates of the Capsicum baccatum seed extract, found that these isolates inhibited the formation of biofilms in $60 \%$ and $80 \%$ for $P$. aeruginosa and S. epidermidis, respectively, due to possible functional activity by terpenes.

Evaristo et al. (2015) also evaluated the antimicrobial activity and antibiofilm activity of a triterpene isolated from leaves Combretum leprosum on Streptococcus sobrinus and Streptococcus sanguinis and suggested that the isolate is a possible biotechnological input with considerable potential for the treatment of infections associated with oral bacteria.

Therefore, it is paramount to search for innovative strategies capable of preventing or minimizing the formation of biofilms, including the study of new compounds, elucidation of possible mechanisms of action and development of materials with anti-infective surfaces.

\section{Conclusions:-}

The latex of $H$. drasticus has a potential antibiofilm action against Gram-negative bacteria (P. aeruginosa ATCC 278553) and Gram-positive (S. aureus ATCC 29213), and may be a viable alternative in the development of nonstick surfaces for clinical practice. However, additional studies should be performed with the purpose of analyzing the plant species from different perspectives, considering the mechanisms of action involved in biological activity.

\section{References:-}

1. Arciola, c. R.; campoccia, d.; speziale, p.; montanaro, 1.; costerton, j. W. Biofilm formation in staphylococcus implant infections. A review of molecular mechanisms and implications for biofilm-resistant materials. Biomaterials, v. 33, n. 26, p. 5967-5982, 2012.

2. Beloin, c.; renard, s.; ghigo, j. M.; lebeaux, d. Novel approaches to combat bacterial biofilms. Curr Opin Pharmacol, v. 18, p. 61-68, 2014.

3. Borowsk, rgv. Avaliação da atividade antibiofilme de Capsicum baccatum var. Pendulum (solanaceae). 100f. 2015. Dissertação (Mestrado em Ciências Farmacêuticas), Universidade Federal do Rio Grande do Sul. Porto Alegre, 2015.

4. Carmo, 1.d. Proteínas isoladas do látex de Himatanthus drasticus (Mart.) Plumel apocynaceae reduzem a resposta inflamatória e nociceptiva na artrite induzida por zymosan em camundongos. 91f. 2015. Dissertação (Mestrado em Farmacologia), Universidade Federal do Ceará. Fortaleza, 2015.

5. Cegelski, 1.; marshall, g. R.; eldridge, g. R.; hultgren, s. J. The biology and future prospects of antivirulence therapies. Nature Reviews Microbiology, v. 6, n. 1, p. 17, 2008.

6. Evaristo, f. F. V.; porto, a. L. F.; magalhaes, j. M.; vasconcelos, m. A.; arruda, f. V. S.; santos, h. S.; bandeira, p. N.; teixeira, e. H. Avaliação da atividade antimicrobiana e antibiofilme de um triterpeno isolado de folhas Combretum leprosum sobre streptococcus sobrinus atcc 6715 e streptococcus sanguinis atcc 10556. Brazilian Jounal of Biodiversity and Biotechnology, p. 1-2, 2015.

7. Grenho, 1.; manso, m. C.; monteiro, f. J.; ferraz, m. P. Adhesion of Staphylococcus aureus, Staphylococcus epidermidis, and Pseudomonas aeruginosa onto nanohydroxyapatite as a bone regeneration material. Journal of Biomedical Materials Research part a, v. 100, n. 7, p. 1823-1830, 2012.

8. Kaplan, m. A. C. Estudos fitoquímicos: barú-janaguba-tabernaemontana. 101f. 1967. Dissertação (mestrado em química), Universidade Federal Rural do Rio de Janeiro. Rio de Janeiro, 1967. 
9. Leite, b. Aderência bacteriana e formação de biofilme aos fios de dermossustentação facial. $120 f .2008$. Dissertação (Mestrado em Bioengenharia), Escola de Engenharia de São Carlos, Universidade de São Carlos, São Carlos, 2008.

10. Lim, k.; chua, r. R. Y.; saravanan, r.; basu, a.; mishra, b.; tambyah, p. A.; leong, s. S. J. Immobilization studies of an engineered arginine-tryptophan-rich peptide on a silicone surface with antimicrobial and antibiofilm activity. ACS Applied Materials \& Interfaces, v. 5, n. 13, p. 6412-6422, 2013.

11. Lucetti, d. L. Avaliação das atividades antiinflamatória e antinociceptiva do acetato de lupeol isolado de Himatanthus drasticus (Mart.) Plumel-apocynaceae (janaguba). 98f. 2010. Dissertação (mestrado em farmacologia), Universidade Federal do Ceará, Faculdade de Medicina, Fortaleza, 2010.

12. Moura, d.f. Avaliação da toxicidade e efeitos biológicos do látex extraído de Himatanthus drasticus (Mart.) Plumel. 53f. 2016. Dissertação (Mestrado em Saúde Humana e Meio Ambiente), Universidade Federal de Pernambuco, Vitória de Santo Antão, 2016.

13. Patocka, j. Biologically active pentacyclic triterpenes and their current medicine signification. J appl Biomed, v. 1, n. 1, p. 7-12, 2003.

14. Pereira, r. S.; sumita, t. C.; furlan, m. R.; jorge, a. O. C.; ueno, m. Antibacterial activity of essential oils on microorganisms isolated from urinary tract infection. Revista de saúde pública, v. 38, n. 2, p. 326-328, 2004.

15. Plumel, m.m. Le genre Himatanthus (apocinaceae) revisión taxonomique. Bradea:boletim do herbarium bradeanu, v.5, p. 1-20, 1991 .

16. Popova, m. P.; chinou, i. B.; marekov, i. N.; bankova, v. S. Terpenes with antimicrobial activity from cretan propolis. Phytochemistry, v. 70, n. 10, p. 1262-1271, 2009.

17. Saeidnia, s.; manayi, a.; gohari, a. R.; abdollahi, m. The story of beta-sitosterol-a review. European Journal of Medicinal Plants, v. 4, n. 5, p. 590, 2014.

18. Soares, f.; fraga, a., neves, j.; romero, n.; bandeira, m. Ethnopharmacological and ethnobotanical study of Himatanthus drasticus (Mart.) Plumel (janaguba). Revista Brasileira de Plantas Medicinais, v. 17, n. 4, p. 900908, 2015.

19. Sparg, s.; light, m. E.; van staden, j. Biological activities and distribution of plant saponins. Journal of Ethnopharmacology, v. 94, n. 2-3, p. 219-243, 2004.

20. Stepanović, s.; vuković, d.; dakić, i.; savić, b.; švabić-vlahović, m. A modified microtiter-plate test for quantification of staphylococcal biofilm formation. Journal of Microbiological Methods, v. 40, n. 2, p. 175-179, 2000.

21. Streeter, k.; katouli, m. Pseudomonas aeruginosa: a review of their pathogenesis and prevalence in clinical settings and the environment. Infection, Epidemiology and Microbiology, v. 2, n. 1, p. 25-32, 2016.

22. Tintino, s. R.; guedes, g. M. M.; da cunha, f. A. B.; dos santos, k. K. A.; matias, e. F. F.; morais-braga, m. F. B.; da costa, j. G. M. Avaliação in vitro da atividade antimicrobiana e moduladora dos extratos etanólico e hexânico de bulbo de Costus arabicus. Bioscience Journal, v. 29, n. 3, p. 1-7, 2013.

23. Trabulsi, 1. R.; alterthum, f. Microbiologia. 5th ed. São Paulo: atheneu; 2009.

24. Trentin, d. D. S.; giordani, r. B.; macedo, a. J. Biofilmes bacterianos patogênicos: aspectos gerais, importância clínica e estratégias de combate. Revista liberato, v. 14, n. 22, p. 113-238, 2013.

25. Zhang, y.; zhang, y. J.; jacob, m. R.; li, x. C.; yang, c. R. Steroidal saponins from the stem of yucca elephantipes. Phytochemistry, v. 69, n. 1, p. 264-270, 2008. 